so doing to reconcile themselves to one another in a mutually acceptable solution.

Obviously, the scientist can only make his full contribution through those who possess not only an understanding of the way in which science works, but also sufficient knowledge to assess the validity of recommendations coming from within a particular field. Such persons must combine personality with their general or particular scientific knowledge, and they must also have a clear perception of the limits of scientific and technical knowledge and of the way in which the methods of open discussion and voluntary agreement function in a parliamentary democracy.

As Sir Ernest Barker points out, democracy which rests merely on the will of numbers rests merely on force. When, for example, a parliamentary government ceases to take account of public opinion or of parliament as a whole and reflects purely the views and wills of the party in a majority, it verges on the autocracy of a totalitarian regime. It ceases to be a democracy in the sense in which that word has hitherto been employed in Britain. The foree which democracy can employ is inadequate merely as force, because democracy must consort with, as it is based. upon, the free and full development of personality. It is not the majority, as a majority, that matters, but each human being as such; and the form of government which we have to find to-day is one which so far as possible elicits and enlists the thought, will, and general capacity, not of a majority but of every member. Such a government depends on mutual interchange of ideas, on mutual criticism of the ideas interchanged, and on the common and agreed choice of the idea which emerges triumphant from these processes. In such a government the influence of the scientific expert can be exerted in the way that is required and that consorts with the method of science itself. It will be a government which rests not on force or on numbers or even on knowledge, but on the spiritual quality of the processes by which it operates; and the effectiveness with which it works depends above all on the personality of those to whom the functions and authority of government are entrusted and the persuasiveness with which they can continuously enlist the understanding, goodwill and participation not of a minority-or even of a majority-but of all the governed.

\section{DE BROGLIE ON QUANTUM THEORY}

\section{The Revolution in Physics}

A Non-Mathematical Survey of Quanta. By Louis de Broglie. Pp. 310. (London: Routledge and Kegan Paul, Ltd., 1954.) 18s. net.

T OUIS DE BROGLIE has a unique place in the history of science as the man who in 1923 propounded the hypothesis of the wave character of material particles and thereby initiated the great movement of thought concerned in the passage from the 'old' to the 'new' quantum theory. His ideas also led directly to vital technical developments represented, in particular, by the invention of the electron microscope. Since then, besides carrying on his own scientific work, he has taken a leading part in scientific education and administration in France. In addition, he has attained eminence as a scientific writer. The present book is a translation by Ralph W. Niemeyer of one of his most notable expository works (with certain additions). Apparently the main text was written in 1936 and revised in 1946, and a few sections added in 1952.

The book may be described as an exposition, following the historical development, of the whole of quantum theory excluding (apart from brief references) the modern quantum theory of fields and modern nuclear theory. The treatment is strictly non-mathematical, but some descriptive indication is given of the mathematical structure of the theory. The work will appeal to several classes of reader. Presumably it is intended primarily for the general scientific reader, other than the mathematician or physicist, who seriously wants to understand the "revolution in physics" that has taken place in the present century. Such a reader will be well rewarded for the attentive study that the author's thorough explanations invite from him. But, since something like classical physics and something like quantum physics must always be necessary, not only for the sake of their appropriate applications, but also on account of the very nature of physical experience, it is essential to understand as well as may be the relation between these two systems; and since a special feature of the book is the statement of this relation as it stands at present, it should also be of much service to the present-day student of physics. Finally, in view of the central part played by the author himself, the book has special significance as a historical record. In this regard, it can be read as an interesting supplement to the recently published second volume of Sir Edmund Whittaker's "History of the Theories of Aether and Electricity", which also supplies the documentation not included in M. de Broglie's account.

Even in describing his own accepted contributions, M. de Broglie avoids the use of the first person singular. He reserves this form of expression for the statement of a few individual speculations and criticisms. These serve to remind us that, great as have been the successes of the theories described, the "revolution in physics" must never be assumed to have resulted in a settled régime.

W. H. McCreA

\section{AN ASSORTMENT OF PROTEINS}

\section{The Proteins}

Chemistry, Biological Activity, and Methods. Edited by Hans Neurath and Kenneth Bailey. Vol. 2, Part A. Pp. $x+661$. (Now York : Academic Press, Inc.; London: Academic Books, Ltd., 1954.) 14 dollars.

THE nine articles that make up this third volume of a four-volume work are, for the most part, good; the information contained in them is well selected and the authors generally approach the statements they are reporting in a pleasantly critical manner. It is therefore more than usually important to consider what the advantage is of having all the articles bound together in one volume, for the con- 